AperTO - Archivio Istituzionale Open Access dell'Università di Torino

Procession as a literary motif: the intersection of Religious and National symbolism in Italian narrative (19th-20th centuries)

This is a pre print version of the following article:

Original Citation:

Availability:

This version is available http://hdl.handle.net/2318/1691154 since 2020-01-06T14:32:10Z

Published version:

DOI:10.1163/18748929-01002005

Terms of use:

Open Access

Anyone can freely access the full text of works made available as "Open Access". Works made available under a Creative Commons license can be used according to the terms and conditions of said license. Use of all other works requires consent of the right holder (author or publisher) if not exempted from copyright protection by the applicable law. 


\section{Procession as a literary motif: the intersection of Religious and National symbolism in Italian narrative $\left(19^{\text {th }}-20^{\text {th }}\right.$ centuries $)$}

\begin{abstract}
E veramente mai fu alcuno ordinatore di 10eggi straordinarie in uno popolo che non ricorresse a Dio; perché altrimente non sarebbero accettate; perché sono molti i beni conosciuti da uno prudente, i quali non hanno in sé ragioni evidenti da poterli persuadere ad altrui. Però gli uomini savi che vogliono tôrre questa difficoltà ricorrono a Dio. [...] E come la osservanza del culto divino è cagione della grandezza delle repubbliche, così il dispregio di quello è cagione della rovina d'esse. Perché, dove manca il timore di Dio, conviene o che quel regno rovini o che sia sostenuto dal timore d'uno principe che sopperisca a' difetti della religione. E perché i principi sono di corta vita, conviene che quel regno manchi presto, secondo che manca la virtù d'esso.
\end{abstract}

Machiavelli $^{1}$

Key words: civil religion; procession; literature; order/disorder; nation; symbols; Italy; Catholicism.

According to Benedict Anderson ${ }^{2}$ and Jean-Pierre Sironneau, ${ }^{3}$ national imagery developed during the Enlightenment as a secular substitute for religion, and modern society has witnessed a "transfer" of sacredness ${ }^{4}$ from the religious to the political sphere, observable in rituals, myths, and community structures. In this paper, I will focus on Italy, where, despite the legal and formal separation of Church and State, the "sacral" national apparatus still owes a considerable debt to religion. After a short exposition of some of the main theories on civil religion in Italy, I will analyze a corpus of Italian novels set during the $19^{\text {th }}$-century Risorgimento, the national

\footnotetext{
${ }^{1}$ Niccolò Machiavelli, Discorsi sopra la prima deca di Tito Livio, (Torino: Einaudi, 2000 [1531]), “And truly never was there yet any maker of extraordinary Laws in a Nation, that had not his recourse to God; for otherwise the Laws had not been accepted. For many several goods are known by a wise man, which have not such evident reasons in themselves, that he by persuasion can quickly make others conceive them. Therefore the wise men, that would free themselves of this difficulty, have recourse to a God [...] and as the observance of Divine Worship occasions the greatness of a Common-wealth, so the contempt of it destroys it. For where the Fear of God is wanting, it must needs be that either that Kingdom goes to ruin, or that it be supported by the awe it stands in of the Prince, who may supply the defects of Religion: and because Princes are but short-liv'd, that Kingdom must needs have an end quickly, according as the virtue thereof fails." Machiavelli, Discourses, 51-52.

2 "What then was required was a secular transformation of fatality into continuity, contingency into meaning [...] few things were (are) better suited to this end than an idea of nation." Benedict Anderson, Imagined Communities, (London \& New York: Verso, 1983), 19.

${ }^{3}$ Jean-Pierre Sironneau, Métamorphoses du mythe et de la croyance (Paris: L'Harmattan, 2000), 38-39.

${ }^{4}$ Sironneau understands "sacredness" as a system of beliefs that shape a group's identity and that are expressed and built through myths, rituals, and social structures. Such beliefs do not have necessarily a theological nature: Sironneau, who focuses on the Western situation, points out how in the secularized age, religion (basically Christian religion) has had to face "political religions" (such as Bolshevism, Nazism, and Fascism). This conception of the "sacral" national apparatus as a system of beliefs, myths, rituals, and social structures can be compared to Anderson's theory of national community as founded on a common imagery and providing both a set of beliefs and a basis for identification and belonging. According to Anderson, the State only has scarce control over the creation of a collective imagery and narratives of the historical events.
} 
unification period, which in Italian culture serves as an atypical founding myth. I will show in particular how civil and religious symbols and rituals intersect in the literary representation of processions. The procession is a frequently recurring motif in Italian contemporary narrative and presents peculiar aesthetic features. The analysis of this literary motif will take advantage of anthropological and sociological theories and will trace a distinction between ordered and disordered, or enthusiastic, processions.

\section{The debate on civil religion in Italy}

In 1531, Niccolò Machiavelli ${ }^{5}$ wrote that the Roman king Numa Pompilio, faced with governing a ferocious people and intending to subdue them without bloodshed, turned to religion. This solution brought him an easy victory, benefited the following generations, and determined Rome's success, ${ }^{6}$ thus showing that no government or state can do without religion and God's awe (see epigraph). Machiavelli therefore anticipated the concept of civil religion, which he envisioned as a cult that is based on a deity, but whose principles are defined by "the prince," i.e. the civil-political authority. The first formulation of the expression "civil religion" was proposed by Jean-Jacques Rousseau. According to Rousseau, the state needs its citizens to believe in a religion that prompts them to fulfill their duties. However, submission to the social contract and the principles of civil religion only concern issues of public morality and social coexistence. As a consequence, civil religion is based on few basic and generic principles - especially that of an omnipotent deity - and it tolerates all forms of worship that do not interfere with its values or with civic duties. ${ }^{7}$

A similar concept was re-elaborated by Robert Bellah, ${ }^{8}$ who identified a civil religion in the United States that differs from the religion of the churches. Civil religion, Bellah explains, does not have a nationalistic character (i.e. it does not consist in the exaltation and veneration of the nation); rather, it is an attitude that interprets national events in light of a universal, transcendent reality. Analyzing a sample of presidential speeches, Bellah proves that civil religion is bound to a generic conception of "God" that can be accepted by all the different denominations existing

\footnotetext{
${ }^{5}$ Machiavelli, Discorsi.

${ }^{6}$ The reference to Rome is extremely pertinent since Roman religion was composed by a State religion (a public worship and pantheon) and a plurality of private cults that did not interfere with the first (e.g. the cult of Lari and Penati, ancestors and spirits protecting the family). On the archaïque substratum in Roman religion, see Georges Dumezil, La religion romaine archaïque, avec une appendice sur la religion des Etrusques (Paris: Payot, 1966). 7 “... les dogmes de cette religion n'intéressent ni l'État ni ses membres qu'autant que ces dogmes se rapportent à la morale, et aux devoirs que celui qui la professe est tenu de remplir envers autrui. Chacun peut avoir au surplus telles opinions qu'il lui plaît, sans qu'il appartienne au Souverain d'en connaître. Car comme il n'a point de compétence dans l'autre monde, quel que soit le sort des sujets dans la vie à venir ce n'est pas son affaire, pourvu qu'ils soient bons citoyens dans celle-ci. Il y a donc une profession de foi purement civile dont il appartient au Souverain de fixer les articles, non pas précisément comme dogmes de religion, mais comme sentiments de sociabilité, sans lesquels il est impossible d'être bon citoyen ni sujet fidèle. [...] Les dogmes de la religion civile doivent être simples, en petit nombre, énoncés avec précision sans explications ni commentaires. L'existence de la divinité puissante, intelligente, bienfaisante, prévoyante et pourvoyante, la vie à venir, le bonheur des justes, le châtiment des méchants, la sainteté du contrat social et des lois, voilà les dogmes positifs." Jean-Jacques Rousseau, Du contrat social, ou Principes du droit politique (Paris: Bordas, 1985 [1762]), 217-218.

8 Robert. N. Bellah (1967) "Civil Religion in America," Daedalus 1 (1967), 1-21, http://www.robertbellah.com/articles_5.htm (accessed on 1 December 2015).
} 
in the nation. ${ }^{9}$ In Italy, the existence of a civil religion was the subject of a lively debate in the second half of the $20^{\text {th }}$ century. Italian authors such as Gian Enrico Rusconi ${ }^{10}$ and Fracesco Traniello $^{11}$ tend to problematize the applicability of the notion of civil religion to Italy, highlighting the difficult relationship between citizens and national institutions or the influence of the Catholic Church. ${ }^{12}$ Discussions on civil religion became particularly frequent and intense in the 1990s, when they extended beyond the academic world and reached even newspapers and television. The topic was deemed particularly relevant and sensitive in years plagued by political scandal ${ }^{13}$ that seriously undermined the credibility of the national state authority.

In 1974, Bellah devoted an essay to "The Five Religions of Modern Italy."14 Bellah's starting point is the concept of the "religion of liberty" elaborated by the philosopher Benedetto Croce ${ }^{15}$ and the responses to Croce's theory generated by critics of Antonio Gramsci. ${ }^{16}$ The "religion of liberty" is liberalism, and Croce identified three other religions in competition with it: Catholicism, socialism, and activism. This last is a parody or perversion of liberalism, an essentially materialistic religion that, according to Croce and Bellah, can be recognized in the works of authors such as Georges Sorel and Gabriele D'Annunzio and that is embodied in Fascism. Gramsci opposed Croce's theory, observing that he would rather call "ideology" or "politics" a concept of religion intended as a non-confessional unity formed by a worldview and a coherent moral code. Bellah retains Gramsci's vision of religion as a historical process and a political system; nevertheless, he prefers to adopt the expression "civil religion" instead of the term "ideology." Indeed, Bellah finds the expression "civil religions" particularly suitable for the Italian context because of the socio-political role Catholicism has always played in the country: the centrality of the Church on the Italian public scene, he argues, determined the development of the other religions as civil competitors of Catholicism.

To the four religions individuated by Croce (Catholicism, liberalism, socialism, activism), Bellah adds a fifth: a pre-Christian or sub-Christian stratum that he calls "religious ground bass" and that, according to him, "precedes temporally, and in a sense, logically, all the others." 17 The ground bass is particularly rooted in Southern Italy and it is based on a local system of loyalty to

\footnotetext{
9 "[... The $]$ only reference was to the concept of God, a word that almost all Americans can accept but that means so many different things to so many different people that it is almost an empty sign." Bellah quotes for example Eisenhower's sentence, according to which "Our government makes no sense unless it is founded in a deeply felt religious faith - and I don't care what it is.” Bellah, Civil religion.

${ }^{10}$ Gian Enrico Rusconi, Patria e Repubblica (Bologna: Il Mulino, 1997).

11 Francesco Traniello, “A proposito di nazione, democrazia e religione civile," in Alessandro Dal Lago (ed.), Identità nazionale e religione civile in Italia, Rassegna italiana di sociologia 2, 255-268.

12 On the debate on civil religion in Italy, see Dal Lago, Identità and Jenny Ponzo, "I discorsi del Presidente Napolitano sull'unità nazionale come professione di fede: per uno studio semiotico della religione civile," Lexia 1112 (2012), 377-394.

${ }^{13}$ In the 1990s the judicial inquiry Mani Pulite showed the corruption of the political class and brought to the fall of the so-called "First Republic." See e.g. Sondra Z. Koff and Stephen P. Koff, Italy: from the First to the Second Republic (London: Routledge, 2000).

${ }^{14}$ The article was first published in Italian. Robert N. Bellah, "Le cinque religioni dell'Italia moderna," in Fabio L. Cavazza, Stephen R. Graubard (eds.), Il caso italiano (Milano: Garzanti, 1974). Transl. "The Five Religions of Modern Italy," in Robert N. Bellah and Steven M. Typton (eds.), The Robert Bellah Reader (Durham and London: Duke University Press, 2006).

${ }^{15}$ Benedetto Croce, Storia d'Europa nel secolo decimonono (Bari: Laterza, 1932).

${ }^{16}$ Antonio Gramsci, Il materialismo storico e Benedetto Croce (Roma: Editori Riuniti, 1971 [1948]).

${ }^{17}$ Bellah, "The five," 56.
} 
the family and to the clan, group or village. It is described as irrational, magical, and much more powerful than the other religions, which are observed only in a formalistic way, i.e. without heartfelt participation. The ground bass "is emotional and intense in contrast to the ascetic rationalism of high Italian culture; it is fiercely closed to the outside world [...], as opposed to the universalism of high Italian thought; and it is presided over by a woman, an epiphany of the Great Mother of the Mediterranean world, only partially and uncertainly articulated with the Virgin of Nazareth." 18

Writing of the religion of Italian peasants, the Italian anthropologist Alfonso Di Nola ${ }^{19}$ also cites

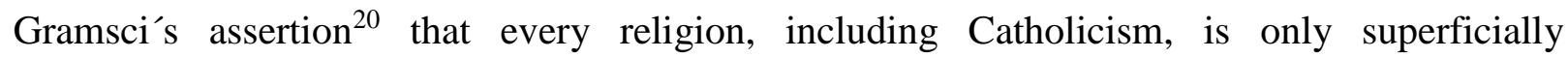
homogeneous, and is actually constituted by a plurality of different local religions: there is a Catholicism of the peasants, one of the bourgeoisie, one of the intellectuals, etc. Adopting a Marxist perspective, Di Nola affirms:

\begin{abstract}
The dependence from the historical-social structures, the impossibility to control the processes of production and the economic dynamics connected to them, and the precariousness of the human labor's results lead to an alienation of one's own individuality and of the product itself. This alienation projects itself in a mythical representation of the nature and of the classist pressure as powers and in a subsequent series of gratifying and offsetting attitudes. ${ }^{21}$
\end{abstract}

Like Bellah, Di Nola acknowledges the presence of non-Christian elements in what he calls the "syncretic" religion, formed by hegemonic and non-hegemonic components. However, he challenges the theory of a pagan and late-antique substratum (with the exception of the cases proved by historical data), instead hypothesizing that the non-Christian elements present in rural beliefs and practices have a medieval and barbaric origin.

In order to describe the ground bass, Bellah references the novel Cristo si è fermato ad Eboli, ${ }^{22}$ in particular the famous episode of the procession, with its almost pagan frenzy and the veneration of the chthonic, archaic Goddess-Virgin Mary. An extensive study of fiction set during the Risorgimento ${ }^{23}$ has demonstrated that the procession is a recurring motif in Italian literature, and that this motif presents some peculiar thematic and aesthetic features. As Massimo Leone $^{24}$ states, a procession is a poetic and metaphorical fact, which explains why it has excited the imagination of poets and artists across the centuries. However, despite the frequency of literary representations of processions, there is a specific reason why this paper focuses on a

\footnotetext{
${ }^{18}$ Bellah, "The five," 57.

${ }^{19}$ Alfonso M. Di Nola, Gli aspetti magico-religiosi di una cultura subalterna italiana (Torino: Bollati Boringhieri, $2001[1976])$.

${ }^{20}$ Gramsci, Il materialismo, 140.

21 "Dipendenza dalle strutture storico-sociali, non dominabilità dei processi di produzione e delle dinamiche economiche loro connesse, precarietà degli esiti del lavoro umano portano a una estraniazione della propria individualità e dello stesso prodotto, la quale estraniazione si proietta in una rappresentazione mitica della natura e della pressione classista come potenze e una conseguente serie di atteggiamenti rituali gratificatori e compensativi." Di Nola, Gli aspetti, 48.

${ }^{22}$ Carlo Levi, Cristo si è fermato a Eboli (Torino: Einaudi, 1954 [1945]).

${ }^{23}$ Cfr. Jenny Ponzo, La narrativa di argomento risorgimentale (1948-2011) (Roma: Aracne), tomes 1-2.

24 Massimo Leone, "Processioni - Il percorso circolare che trasforma," Golem Indispensabile (2002), http://www.golemindispensabile.it (available here: https://www.academia.edu/176893/2002_Processioni__Il_percorso_circolare_che_trasforma, accessed 2 November 2015).
} 
corpus of novels set during the Risorgimento. Before proceeding with the analysis of the literary texts, I will therefore spend some time discussing the role of the Risorgimento in the Italian problematic "civil religion."

\section{Risorgimento as a founding myth?}

As Sironneau ${ }^{25}$ points out, national identity is based on a set of founding myths. The coexistence of a plurality of funding myths is due to the fact that different groups (ethnic, linguistic, and social groups, etc.) compose the nation, and also to the fact that identity changes over time and is derived from many founding events and from many different, and sometimes contrasting, accounts of such events. In the members of the community, however, these differences create a consciousness of common belonging. National identity is therefore never unidimensional, but is the result of the articulation of multiple identities; it is inscribed in time and has a narrative character:

For a nation, to understand its identity means not only to refer to founding events in a distant past, but it means to understand it starting from a system of differentiations articulating themselves [...] in time; in this process, the successive accounts play an essential role: it is by producing an account that the nation, which is a collective subject, builds its identity; it is through this narrative that a people preserves itself: it takes possession of its own being through a series of successive interpretations; by telling itself, it acquires an identity of its own, and it loses this identity when it becomes the object of the narration of another people. From this, it clearly emerges how important are for a people those multiple accounts which are the successive foundational myths, the legends, as well as the mythologized history that, especially in the West, since the Middle Ages contributes to the formation of the peoples' collective consciousness. ${ }^{26}$

In contemporary societies, the narration of history no longer relies on overt mythology: as MarieDominique Perrot, Gilbert Rist, and Fabrizio Sabelli observe, myths are replaced by stories which are not labelled as "tales." Contrary to previous tradition, such stories feature human beings (and not supernatural agents) as actors and strive to establish a neat division between past and present. Referencing the theories of Michel de Certeau, ${ }^{27}$ the three authors affirm that history is the myth of contemporary culture:

"[History] creates a theater of references and of common values granting to the group symbolic unity and communicability;" just like myth [...], history is an efficacious tale: "claiming to tell the real, it constructs it. It is performative." 28

\footnotetext{
${ }^{25}$ Sironneau, Métamorphoses.

26 "Pour une nation, comprendre son identité, ce n'est pas seulement se référer à des événements fondateurs situés dans un passé lointain, c'est la comprendre à partir d'un jeu de différenciations qui s'articulent [...] à travers le temps; dans ce processus les récits successifs jouent un rôle essentiel: c'est en produisant un récit que ce sujet collectif qu'est une nation construit son identité; c'est par cette narrativité qu'un peuple se maintient: il s'approprie de son être à travers une série d'interprétations successives; en se racontant, il acquiert une identité propre et perd cette identité quand il devient l'objet de la narration d'un autre. On voit par là l'importance que revêtent pour l'identité d'un peuple ces multiples récits que sont les mythes successifs de fondation, les légendes, sans oublier l'histoire mythologisée qui, en Occident surtout, depuis le Moyen-âge contribue à former la conscience collective des peuples." Sironneau, Métamorphoses, 46.

${ }^{27}$ Michel de Certeau, "L'histoire, science et fiction," Le genre humain 7-8 (1983), 151-152.

28 “"elle crée un théâtre de références et de valeurs communes qui garantissent au groupe une unité et une communicabilité symboliques'; comme le mythe [...], l'histoire est un récit efficace: 'en prétendant raconter du réel, il en fabrique. Il est performatif'." Marie-Dominique Perrot, Gilbert Rist and Fabrizio Sabelli, La mythologie programmée: l'économie des croyances dans la société moderne (Paris: PUF, 1992), 41.
} 
Marc Bloch ${ }^{29}$ likewise points out that the modern mentality places a high value on reflection on the past as a means of understanding the present, a need which is perceived as particularly urgent in times of crisis. Bloch connects this tendency to the concept of "origins" and the "obsession with the origins" that was introduced by Christian thought in Western culture. Bloch is here citing one of the most famous theoreticians of the concept of nation, Ernest Renan, who in 1882 affirmed that shared memory, together with language and religion, is one of the essential components of the nation. However, Renan warned that in order to foster national union, history cannot present itself as a random set of events: the facts must be suitably selected, interpreted, and narrated. ${ }^{30}$ It is evident, therefore, that the narration and interpretation of history, and especially of founding deeds, is an important aspect of the identity of a modern nation; besides, we see that "founding myths" should be considered an essential part of what we call "civil religion." We can add that, together with historiography, fictional literature plays a significant role in this process of narration and interpretation of national history. Reaching a broad nonspecialist audience, literature represents and spreads ideas in the national community, and often functions as a bridge between the intellectual and the other classes.

In Italian culture, the Risorgimento (the historical period of Italian national unification) constitutes an atypical founding myth, because it is often represented in its negative aspects. However, it is certainly true that 20th-century authors often use the Risorgimento in order to speak about problems of their time. This characteristic is particularly evident in fictional literature, where the Risorgimento is represented as a source of problems affecting today's Italy, or appears as a metaphor to speak of difficult subjects, or becomes the touchstone for a comparison between past and present. ${ }^{31}$ For example, Leonardo Sciascia ${ }^{32}$ presents the historical event narrated in I pugnalatori (see below) as the first occurrence of the terroristic "strategy of tension" that shook Italy during the "lead years" (1970s). Other authors, such as Andrea Camilleri $^{33}$ and Carlo Alianello, ${ }^{34}$ depict the historical circumstances of the Risorgimento as playing a role in empowering the mafia and establishing its blameworthy relationship with national institutions. Numerous authors, such as Alianello, ${ }^{35}$ Anna Banti, ${ }^{36}$ and Luciano Bianciardi, ${ }^{37}$ ascribe the definitive defeat of the ideals of justice and equality, as well as the rise of the corrupted ruling class that is still leading Italy today, to the Risorgimento. The famous novel Il Gattopardo ${ }^{38}$ presents the Risorgimento as a moment of transition when Italy's traditional, aristocratically led society gave way to the modern society led by an ambitious and petty bourgeoisie. The Risorgimento is also generally represented as the origin of the wealth disparity between Northern and Southern Italy, of the growth of the first and the impoverishment of the second.

\footnotetext{
${ }^{29}$ Marc Bloch, Apologie pour l'histoire ou métier d'historien (Paris: Armand Colin, 1993 [1949]).

${ }^{30}$ See Ernest Renan, Qu'est-ce qu'une nation?: Texte intégral (Paris: P. Bordas et fils, 1991 [1882]), 34 and 41.

${ }^{31}$ See Ponzo, La narrativa.

${ }^{32}$ Leonardo Sciascia, I pugnalatori (Milano: Adelphi, 2007 [1976]).

${ }_{33}$ Andrea Camilleri, La bolla di componenda (Palermo: Sellerio, 1993).

${ }^{34}$ Carlo Alianello, L'eredità della priora, Venosa, Osanna (2011b [1963]).

${ }^{35}$ Carlo Alianello, L'alfiere (Milano: Rizzoli, 2011a [1942]); Alianello, L'eredità.

${ }^{36}$ Anna Banti, Noi credevamo (Milano: Mondadori, 1967).

${ }^{37}$ Luciano Bianciardi, Le cinque giornate. Bisognerebbe anche occupare le banche (Viterbo: Stampa alternativa, 2008 [1969]).

${ }^{38}$ Giuseppe Tomasi di Lampedusa, Il Gattopardo (Milano: Feltrinelli, 1958).
} 
The Risorgimento therefore plays an important role in the definition of national identity, at least in its literary representation. If a "civil religion" exists in Italy, Risorgimento - as a (atypical) founding myth - is certainly one of its basic narrative components. Furthermore, given its civil subject, fiction set during the Risorgimento offers abundant examples of processions in which religious and national symbolisms are often related. We will focus on the nature of this relationship, and in particular on two opposing dynamics: the passage from civil action to religious ritual, and the passage from religious ritual to civil action. Furthermore, we will see how these dynamics are connected to the binary opposition order/disorder.

\section{From revolution to religious procession}

It is difficult to draw a clear distinction between civil cortèges and religious processions in Italian literature set during the Risorgimento. One finds both processions following symbols of religious-spiritual authority, and processions rather following symbols of secular, earthly authority. Nevertheless, religious and political motifs are often intermingled: on the one hand, some civil cortèges adopt Catholic rituals and symbols, while, on the other hand, there are Catholic processions in which the prevailing component is not religious, but socio-political or ideological.

For example, the short novel Lo stivale di Garibaldi, ${ }^{39}$ set in a Sicilian village, centers on the controversy between the prefect of the new national state and a Garibaldi's veteran. The controversy concerns the organization of a procession in honor of a secular relic, the boot worn by Garibaldi when he was hurt at the heel. After many diplomatic skirmishes and despite the opposition of the prefect, the procession takes place, and it displays features of a religious procession for the saints, with kneeling, crying women and obsequious men with hat in hand. Similarly, in L'eredità della priora the people of Melfi, in Basilicata, celebrate the success of the brigand Crocco, who has occupied the city claiming to fight for the restoration of the Bourbon king, while the people of Potenza venerate a portrait of Garibaldi, whose army has won the Bourbon:

\footnotetext{
This stupid people made Crocco sit on a throne, surrounded by lighted candles. It seemed the Sepulcher of the Holy Thursday; he had the portrait of Maria Sofia on the one side, and the portrait of Francesco on the other side... I mean of His Majesty. ${ }^{40}$

They made the lighting with the Venetian lanterns, which the rain soaks right away and makes die out. And now they are bringing in a procession along the Pretoria road the portraits of Vittorio Emanuele and Garibaldi. [...] Hurrah! Hurrah! Hurrah for the unified Italy! ${ }^{41}$
}

\footnotetext{
${ }^{39}$ Adrea Camilleri, Lo stivale di Garibaldi (Catania: Stilos, 2010).

40 “[Crocco] Stu popolo fesso l'ha messo a sedere in trono, in mezzo alle candele accese, che pareva il Sepolcro del Giovedì Santo, col ritratto di Maria Sofia da una parte e quello di Francesco dall'altra... Voglio dire di sua Maestà." Alianello, L'eredità, 187. Translations into English by the author, except where otherwise noted.

41 "Hanno fatto l'illuminazione coi palloncini alla veneziana, che la pioggia subito infradicia e spegne e adesso stanno portando in processione per la strada Pretoria i ritratti di Vittorio Emanuele e di Garibaldi. [...] Evviva! Evviva! Viva l'Italia unita!' Alianello, L'eredità, 552.
} 
Popular political opinion is unstable and changes quickly. However, no matter their orientation, liberal or conservative, the way in which people celebrate their leaders is always the same and owes much to Catholic liturgy and tradition. Another example is provided by the tale Il Quarantotto, set in a Sicilian village. The revolts and the revolutionary spirit that burst out in 1848 are overcome and neutralized by the powerful local bishop, who organizes a procession in honor of the "liberal" pope Pius IX:

The following day, the Pope's portrait was marched round again. A procession formed, starting from the Bishop's palace, with the Bishop leading, giving his blessing, smiling and raising his eyes to the balconies, which were so crowded it looked as if they would overflow. On the Bishop's right was the Baron, dressed in subfusc, with two or three Papal decorations [...]. Behind them came the rest of the Committee, twenty or so people, then the Guilds and their standards. The procession halted in the Piazza, the Bishop came to the balcony of the Town Hall to bless and smile. Then Dr. Amato gave a speech, which was all against the Bourbons and the police [...], he spoke of liberty, quoting lines from famous poets; and ended by declaring his love for the town of Castro and for all Sicily. After him, the Canon Liotta came up to speak, and said that the people of Castro deserved praise for the moderation, good sense and harmony they had displayed in exemplary fashion. It was a sure sign for a better future [...] and he concluded that only the fear of God and love for one's neighbour could give true happiness to the Sicilians. ${ }^{42}$

It is clear in this passage that the religious dimension is strictly connected to the political one: the procession starts from the palace of the bishop, who then blesses the audience from the town hall, where the local notables pronounce political speeches. Even while apparently exalting the freedom endorsed by the liberal-revolutionary party, the bishop and the civil authorities are actually suppressing the revolution. They do so in two ways: firstly, the procession provides a ritual and rhetorical scheme, an ordered manifestation that disciplines and submits the revolutionary impulse. Secondly, the feast in the streets after the official ceremony provides a liberating, cathartic moment, thus venting the people's subversive energies.

Alianello describes the happiness of these kinds of post-revolution and post-ritual feasts (in this case, the feast following the procession in honor of the image of the brigand Crocco) in dark tones, as an irrational euphoria that will have negative consequences:

... those continuous, restless screams, which were of joy, but someone hearing them from afar, someone walking on the mountains in the night, could mistake them for the mooing of a whole herd felt down in the ravines $[. .$.$] like the echo of an interminable agony... { }^{43}$

\footnotetext{
42 "L'indomani ancora fu portato in giro il ritratto del papa: partendo dal palazzo vescovile si formò una processione, in prima fila il vescovo benedicente, e sorrideva alzando gli occhi ai balconi, così fitti di persone i balconi che pareva ne dovesse grondar fuori qualcuna; a destra il vescovo aveva il barone, vestito di scuro e ornato di due o tre onorificenze pontificie [...]. Dietro venivano gli altri del Comitato, una ventina di persone; e poi le Corporazioni con gli stendardi. In piazza la processione si fermò, il vescovo si affacciò al balcone del municipio a benedire e sorridere; poi fece un discorso il medico Amato, tutto contro il Borbone e la polizia [...], della libertà parlò citando versi di poeti grandi; e finì dichiarando amore al paese di Castro e alla Sicilia tutta. Dopo di lui prese la parola il canonico Liotta e disse che il popolo di Castro meritava elogio per la moderazione il buon senso la concordia di cui dava prova ed esempio: auspicio sicuro di un destino migliore [...] e concluse che solo il timor di Dio e il rispetto del prossimo potevano dar giusta felicità ai siciliani." Leonardo Sciascia, "Il Quarantotto," Gli zii di Sicilia (Torino, Einaudi, 1978 [1958]), 126-127. Transl. "Forty-Eight," 113-114.

43 “... quell'urlìo continuo, senza riposo, che era di gioia, ma chi l'avesse inteso di lontano, uno che andasse tra $\mathrm{i}$ monti di notte, lo poteva scambiare per il muggito d'un armento intero precipitato giù per le forre [...] come l'eco d'una interminabile agonia..." Alianello, L'eredità, 190-191.
} 
In the street, the hubbub that lasted all night long was agitated with a happiness which was not sure and maybe already paid off. The reasonable people thought that the new Italian kingdom, up to that moment, had only employed the minimum of its actual forces, army and police, against the disheveled and ragamuffin mass of peasants that wanted to be called reactionaries, patriots or partisans. The real match had not started yet; the plebs were obscurely conscious of that, and they thought that one hour of pleasure is worth one hundred years of troubles. The screams, the shouts, the laughs, and the songs gloomily resounded in the night. The lords rolled whole barrels of wine out of the black and cold caves, so as to satisfy the plebby thirst and as a trench to protect other goods; more substantial and dear goods, where the hand of the common people must not arrive. The people ate, drank and enjoyed shouting "Viva Francesco! Death to Gallobardo!"44

The neo-avant-gardist novel Le armi l'amore narrates in surreal tones the story of Carlo Pisacane and his men, revolutionaries who wanted to free Southern Italy but were massacred by the population. The peasants of the Mezzogiorno are represented as an unselfconscious mass, trapped into a motionless, timeless, and stagnant dimension. In this context, the acts of singing and orderly following the priest and the religious symbol opening the procession are described as purely "mechanical" actions:

$3 \quad \ldots$ and between the dark curtains of the alley he will see the apparition of the swinging design of the fountain, the two nymphs barely covered by some shred of stone sculpted in draperies [... the silent burst of heat] will occupy the whole square of the piazza, nuancing the design of the fountain of the houses of the church and adulterating all the profiles inside the empty piazza: and the swallows will rigidly glide fan-shaped on the widening, fluttering all together just in time to rise up again as quick as lightening, one moment before they hit the façade of the palace decorated by the big stone emblem above the portal, [...] and then some wind will slowly cross the piazza, lightly agitating the image of the saint on the embroidered standards, among the red threads of the flames and the cloth on the arches tended between two poles, and making the colored papers on the small altars rustle among the extinguished candles in the halls, and then [... the revolutionaries] will stop at the edge of the piazza at the entrance of the alley, still watching around them, as if what they will have seen turning up in the bright square of the piazza had induced them to watch around them in order to find something that could justify or explain that apparition, creating around it a plausible environment, like a rural piazza decorated for a feast - although completely empty - thus giving it at least a shade of likeliness: meanwhile, behind the flowerpots placed as a semicircle in front of the palace door, the old woman will continue to clutch herself with her gloved hands to the huge seat of golden wood, buried in a white dress similar to a wedding dress, and the two women, one at each side of that kind of a throne, will watch each other's faces and stay motionless [...] until the swinging shadow of the damask canopy will move on the cobbles of the piazza and the priest will start singing a chant with a hesitating voice and the men the women and the children that will follow him holding the heavy torches of carved wood will start singing without being able to go together, evidently too busy observing the still men at the edge of the piazza with the rifles in their hands, while also the men holding the canopy will turn to watch walking each on his own, so that the poles will disorderly move to and fro and the damask of the canopy will loosen as if it was going to fall down wilting $[\ldots]$ and the priest will pass holding high the silver sun of the monstrance, as if he wanted to use it to protect his face, and then he will stop in front of the portal of the palace and [...] move up to the flowerpots and bless the old woman with the monstrance while the old woman will lift or rather will succeed in unnailing one hand from the arm of her throne and slowly moving it she will make the sign of the cross [...] and then -

44 "In istrada la baraonda che durò tutta la notte smaniava d'una felicità non sicura e forse già scontata. La gente sensata pensava che il nuovo regno d'Italia fino a quel punto non aveva mosso che un minimo della sua vera forza, esercito e gendarmeria, contro la massa sbracata e stracciona dei cafoni che si facevano chiamare reazionari, patriotti o partigiani e la partita vera ancora doveva cominciare; la plebe, oscuramente conscia, pensava che un'ora di gusto vale cento anni di guai e le urla, gli strilli, le risate e i canti rimbombavano nella notte, lugubremente. I signori avevano fatto rotolare intere botti di vino fuori dalle grotte nere e fredde, a soddisfare la sete plebea e a fare da trincea ad altri beni; più sostanziosi e più cari, dove la mano del popolo basso non ci doveva giungere. [...] il popolo mangiava, beveva, ballava e si spassava strillando: 'Viva Francesco! Morte a Gallobardo!'”Alianello, L'eredità, 190. 
2 the chant will continue to sway, off-key, disorderly, while the people following the procession will still look around, anxiously, as if they were scared at the idea of what they would have to decide to do when they would not have to do those mechanical acts of following a procession and signing anymore - the whole procession $[\ldots]$ will disappear on tiptoe, slow and agitated, in the dark of the church... ${ }^{45}$

This passage symbolizes the whole social structure of Southern Italy's traditional society. It is possible to identify three main components: (1) the "ground bass," (2) Christianism, and (3) the earthly authority, signaled by the respective numbers in the quotation.

\section{The "ground bass"}

In the passage there are three interrelated icons: the stereotyped mythological figures of the fountain, the statue of the saint brought in procession, and the old lady, similar to a wooden sculpture on a golden throne. The throne, the flowers at her feet, and her virginal wedding dress evoke both the woman of the feudal aristocracy and a deformation of Marian iconography. Later in the novel, we learn that this lady was a beautiful girl, kept isolated by a possessive father with whom she had an incestuous relationship. After her father's death, the woman lives alone in her palace, claiming to be "not a saint but much more" and undergoing a metamorphosis into a statue or relic. In traditional society, women are treated as objects (or non-subjects), but at the same time they are attributed with an aura of sacredness: they are reified as sanctified, venerated objects. If this fetishization of the woman aims at neutralizing an obscure power of hers, she is nevertheless the "master of the whole village."

45 “... e tra le due quinte buie del vicolo lui vedrà apparire il disegno oscillante della fontana, le due ninfe coperte appena da qualche brandello di pietra scolpita in panneggi [...la vampata silenziosa] occuperà tutto il quadrato della piazza sfumando il disegno della fontana delle case della chiesa e alterando tutti i profili dentro la piazza vuota: e le rondini si abbatteranno stridendo rigide a ventaglio sullo slargo, frullando tutte insieme le ali giusto in tempo per rialzarsi fulmineamente [...] un attimo prima di sbattere contro la facciata del palazzo decorato dal grosso stemma di pietra sopra il portone, [...] finché un po' di vento attraverserà adagio la piazza agitando appena sugli stendardi ricamati l'immagine del santo tra il filo rosso delle fiamme e la stoffa sugli archi tesi da un palo all'altro, e facendo frusciare negli androni le carte colorate degli altarini fra le candele spente, e allora [... i rivoluzionari] si fermeranno sull'orlo della piazza all'imboccatura del vicolo guardandosi ancora intorno, come se quanto avranno visto sbucando nel quadrato luminoso della piazza li avesse indotti a guardarsi intorno per cercare qualcosa che potesse giustificare o spiegare quella apparizione, creandole attorno un ambiente plausibile, come una piazza di paese addobbata a festa - anche se completamente vuota - e dandole così almeno un'ombra di verosimiglianza: mentre, dietro i vasi di fiori disposti a semicerchio davanti alla soglia del palazzo, la vecchia continuerà ad avvinghiarsi con le mani guantate ai braccioli dell'enorme seggiolone di legno dorato, sepolta in un vestito candido simile a un abito da sposa, e le due donne, una per parte ai lati di quella specie di trono, si guarderanno in faccia restando immobili [...] finché l'ombra ondeggiante del baldacchino di damasco si muoverà sull'acciottolato della piazza e il prete intonerà un canto con voce esitante e gli uomini le donne e i bambini che lo seguiranno reggendo le pesanti torce di legno scolpito incominceranno a cantare senza riuscire a andare insieme, evidentemente troppo occupati a guardare gli uomini fermi ai bordi della piazza con i fucili in mano, mentre anche gli uomini che reggeranno il baldacchino si volteranno a guardare camminando ognuno per conto suo in modo che le pertiche si sposteranno disordinatamente avanti e indietro e il damasco del baldacchino si allenterà come se stesse per precipitare afflosciandosi [...] e il prete passerà tenendo alto il sole d'argento dell'ostensorio come se volesse servirsene per proteggersi la faccia e poi si fermerà davanti al portone del palazzo e [...] avanzerà fino ai vasi di fiori e benedirà la vecchia con l'ostensorio mentre la vecchia solleverà o piuttosto riuscirà a schiodare una mano dal bracciolo del suo trono e muovendola lentamente si farà il segno della croce [...] e poi - il canto continuerà a ondeggiare, stonato, in disordine, mentre la gente al seguito della processione si guarderà ancora intorno, ansiosamente, come se fosse impaurita all'idea di quello che avrebbe dovuto decidersi a fare quando non avesse più avuto da fare quegli atti meccanici di seguire una processione e di cantare - l'intera processione [...] scomparirà in punta di piedi, lenta e agitata, nel buio della chiesa..." Emilio Tadini, Le armi l'amore (Milano: Rizzoli, 1989 [1963]), 175-178. 
Another female character, an English journalist, states that Italian men are weak and instinctively dread every woman except their mother: this is why "Italians adored their true and only deity in a mother, whose virginity was moreover granted and inaccessible. This was the most reassuring thing that an Italian could wish, since it did not offend his unlimited potential jealousy, and it did not challenge his poor initiative." 46 A mother-goddess is therefore the Italians' real deity. This statement seems to refer to the theories of the Great Mother, which flourished in the second half of the $20^{\text {th }}$ century and claimed that the Indo-European religions and Christianism superseded a previous prehistorical religion founded on a feminine deity and an equal society. In these kinds of theories, the Virgin is often interpreted as a symbol that neutralizes the explosive (or potentially revolutionary) power of the Great Mother. ${ }^{47}$

Furthermore, the images of the procession and the feminine deity can be connected to Bellah's concept of the ground bass, elaborated with Carlo Levi's novel as a starting point. There are several common elements in Levi's and Emilio Tadini's works: the representation of the South as a poor, arid, and static land; the peasants as beasts of burden (on the opening page of Levi's novel); the pettiness of the people's material desires; and the omnipresent ruins of a forgotten past. Another common element is the description of the procession. ${ }^{48}$ While Levi's procession has an enthusiastic character, Tadini's ritual (quoted above) is ordered and mechanical. However, there are other passages in Tadini's novel where the enthusiastic component is heavily accentuated, including the conclusive episode of the murder of the revolutionaries (see below) and the episode of the desecration of the statue of the king, where a mass of people under the sway of an irrational euphoria moves circularly around the monument in the square, like an overwhelming swell of water. Southern Italy's social and religious base or substratum is therefore represented by a feminine deity with an extraordinary emotive magnetism. This goddess structures the role of the woman, which is placed at the foundation of social order and is the object of desires of possession, control, and protection.

\section{Christianism}

In Tadini's description of the piazza, the sculptures on the façade of the church evoke an omnipotent masculine deity. In the Christian religion, the feminine deity is placed in a deep stratum and in a subordinated position. Christianism represents the most powerful system of values shaping traditional social hierarchy. The narrator states that God, the fundamental principle, requires the total sacrifice of human beings in the name of a reward that will take place after death ${ }^{49}$. This ideology is presented as the first deformation of a series of subsequent deformations shaping social organization. Indeed, the immensity of the church's façade dominates the aristocratic palace, the fountains, and the miserable "lairs" of the poor. Furthermore, those who will kill the revolutionaries are not political enemies, but peasants, and

\footnotetext{
46 “... gli italiani adoravano la loro vera e unica divinità proprio in una madre, la cui verginità, per giunta, era assolutamente garantita e inaccessibile, il che era quanto di più rassicurante un italiano potesse desiderare dato che non offendeva la sua illimitata gelosia potenziale e insieme non provocava il suo povero spirito d'iniziativa." Tadini, Le armi, 33-34.

${ }^{47}$ See e.g. Riane Eisler, The Chalice and The Blade: Our History, Our Future (San Francisco: Harper Collins, 1987).

${ }^{48}$ Levi, Cristo, 31, 105-107, 130.

${ }^{49}$ See in particular Tadini, Le armi, 188-190.
} 
they are represented not as the king's subjects, but as the faithful following a procession (see below).

\section{The earthly authority}

The inhabitants of the palace represent the traditional aristocracy and earthly power more generally. The palace is connected to the fountain, which displays the prestige of the lords, who believe they can offer their subjects "a portion of beauty," as if they had the power to impose even aesthetic values. ${ }^{50}$ This succinct explanation of the dense symbolic and social meaning of the spatial structure of the square ${ }^{51}$ can help us to fully grasp the meaning of the procession crossing it. The ritual is described as a habit that has shaped human life from immemorial time. As a consequence, the faithful, accustomed to subjection, are worried about the changes that the revolutionaries could bring about: what will they do when their mechanical actions are interrupted and they have to make decisions, when the scheme of ritual and social determination is no longer a viable option? The concept of necessity can be a good lens through which to read this passage. As Clifford Flanigan writes, "processions give their participants a feeling of necessity, that this movement is taking place because it, and what implicates and signifies, must unavoidably be so and not otherwise." ${ }^{, 52}$ This feeling of necessity is an excellent way to explain the people's distress when they must face the perturbing element represented by the presence of the foreign revolutionaries on the square.

Furthermore, Tadini's description of the procession can be interpreted as a literary equivalent of Di Nola's theory of the "alienation of individuality," which was heavily informed by the Marxist perspective that was widespread in the Italian intellectual milieu of the 1960s-70s. According to this kind of theories, Christianism subjugates and annihilates the subjectivity of the person through mechanical ritual. The above-mentioned image of the subsequent deformations, for example, recalls the famous image of the "camera obscura." 53

In Italian literature set during the Risorgimento, the community is often represented as a nonsubject, ${ }^{54}$ that is, as a mass deprived of self-consciousness and dominated by civil and religious institutions. The lack of subjectivity and the submission of the people are often represented through the motif of the procession, implying the act of following or trailing after a symbol of power and suggesting strong, elementary, and collective passions. Other surprisingly recurring

\footnotetext{
50 Tadini, Le armi, 185-186.

${ }^{51}$ For a more detailed analysis see Ponzo La narrativa; “Genius loci et identité nationale: representations de 1'espace dans la narrative italienne sur le Risorgimento," Paola Polito and Alberto Roncaccia (eds.), Entre espace et payseage. Pour une approche interdisciplinaire (Lausanne: Etudes de Lettres, 2013), 167-182; "Le opere d'arte come simboli politici nella narrativa sul Risorgimento (XX secolo)," Elena Pirvu (ed.), L'italiano nel mondo, a 150 anni dall'Unità d'Italia. Atti del convegno internazionale di studi di Craiova, 16-17 settembre 2011 (Craiova: Universitaria), 370378.

${ }^{52}$ Clifford C. Flanigan (2001), "The Moving Subject: Medieval Liturgical Processions in Semiotic and Cultural Perspective," in Kathleen Ashley \& Wim Hüsken (eds.), Moving Subjects. Processional Performance in the Middle Ages and the Renaissance (Amsterdam \&Atlanta: Rodopi, 2001), 40.

${ }^{53}$ Karl Marx \& Friederich Engels, Die deutsche Ideologie: Kritik der neuesten deutschen Philosophie in ihren repräsentanten, Feuerbach, B. Bauer und Stirner, und des deutschen Sozialismus in seinen verschiedenen Propheten 1845 - 1846 (Wien: Verlag für Literatur und Politik, 1932).

${ }^{54}$ According to Algirdas J. Greimas \& Joseph Courtès, Sémiotique: dictionnaire raisonné de la théorie du langage (Paris: Hachette, 1979), tome 1, 179-180, a subject is defined by the fact of adopting a system of values and acting according to them. A subject is therefore self-conscious and acts according to his will in order to obtain his values.
} 
elements representing non-subjectivity are metaphors and similitudes comparing the poor and exploited to animals, objects or work tools. ${ }^{55}$

\section{The political and theatrical dimension of religious processions}

The political dimension of religious processions is evident in many other texts, e.g. I pugnalatori (Sciascia), Un filo di fumo ${ }^{56}$ (Camilleri), and Le cinque giornate (Bianciardi). Bianciardi describes a religious procession in Milan that has such an accentuated political dimension that the revolutionary protagonist agrees to take part in it:

Even if I have never been a good faithful, I attended the solemn procession which, on that September day, crossed half of the city, from Sant ${ }^{\prime}$ Eustorgio to the Duomo, an endless row. Everyone wore the vestments of the solemn occasions and shook censers, flabellum, monstrances, and other Church tools. Along the way they had constructed three triumphal arches, dedicated to the Lombard saints, I mean Ambrogio (who, for precision's sake, was from Trier, like Karl Marx), Carlo and Galdino. [...] Even the podestà Ferrari took part in the procession [...] and we shouted together with the others hurrah for pope John, and hurrah for Italy. ${ }^{57}$

The procession is described using a surreal mix of facts and characters of the Risorgimento and of the second half of the $20^{\text {th }}$ century: this temporal confusion recurs in the whole novel. The quoted passage shows the irony that the narrator sees in the "clerical stuff" characterizing the ritual. Moreover, the attention devoted to the three arches offers a good example of how the procession organizes space and time, giving them "a meaningful structure." ${ }^{58}$ It does so by selecting a particular itinerary and a rhythm based on different stopping points. Each stop has a symbolic meaning that can be religious, but also explicitly socio-political. Rossella Merlino, for instance, reports that Sicilian processions traditionally stopped in front of the houses of the local mafia bosses, and that this practice was widespread until very recently. ${ }^{59}$ In fictional processions, too, we witness the socio-political organization of the space: in Bianciardi, the three arches celebrate the "patriotic" saints, while Tadini describes the procession stopping in front of the old woman's palace, representing the traditional ruling class. Noteworthy is also the attention that Sciascia (see above), Camilleri, and Alianello (see below) devote to describing the hierarchical disposition of the social classes in the procession. As Louis Marin ${ }^{60}$ observes, the "internal syntax" - i.e. the order in which the participants and the symbols are disposed - is an important part of the message that a procession conveys.

\footnotetext{
${ }^{55}$ On this subject, see Ponzo La narrativa, tome 2, chapter 1.

${ }^{56}$ Andrea Camilleri, Un filo di fumo, in Romanzi storici e civili (Milano: Mondadori, 2004 [1980]), 4-107.

57 "Io, che non sono mai stato un buon fedele, assistei tuttavia alla solenne processione che quel giorno di settembre percorse mezza città, da Sant'Eustorgio fino al duomo, una fila che non finiva mai, tutti indossando i paramenti delle ricorrenze solenni e agitando turiboli, flabelli, ostensori e altri attrezzi di chiesa. Lungo la strada avevano alzato tre archi trionfali, dedicati ai santi lombardi, voglio dire Ambrogio (che a voler essere pignoli però era tedesco di Treviri, come Carlo Marx), Carlo e Galdino. [...] Alla processione partecipò anche il podestà Ferrari [...] e insieme gridammo con gli altri viva papa Giovanni, e viva l'Italia." Bianciardi, Le cinque, 69.

${ }^{58}$ Louis Marin, "Notes on a Semiotic Approach to Parade, Cortege, and Procession," in Alessandro Falassi (ed.), Time out of time. Essays on the festival (Albuquerque: University of New Mexico Press, 1987), 223.

${ }^{59}$ Rossella Merlino (2014), "Sicilian Mafia, Patron Saints, and Religious Processions: The Consistent Face of an Ever-Changing Criminal Organization," Californian Italian Studies 5/1, 109-129. Merlino also reflects on the prominent role of the mafiosi in the organization and performance of the ritual and on the value of this participation for the affirmation of the mafia's power.

${ }^{60}$ Marin, "Notes."
} 
In Un filo di fumo, for example, the trader Barbabianca and his family triumphantly enter the church, where the whole village is gathered. Although the family is not observant at all - with the exception of the sanctimonious son Stefanuzzo -, Barbabianca holds an ex-voto for the averted danger of the crash, which the whole community had wished for. The meaning of Barbabianca's action is more social than religious:

The function took place at the Matrice, and it was something very solemn, which deserved to be told and seen. At ten in the morning, in the middle of two wings of singing altar boys and a crowd of warehousemen, warehouse boys, employees, all with the respective wives, Stefanuzzo Barbabianca showed up at the door of the church, barefoot and with a lighted candle in his hand, in order to fulfill his second vow. With his head down on his breast, the candle lifted up, he arrived at the main altar, where he stopped in due concentration. Then [...] he lay down, and dragging himself [...] he accurately licked the dirt off the pavement with his tongue, sweeping twice the whole church [...]. After the fulfillment of the vow, the procession took shape, ahead an altar boy holding the tablet on a satin pad [... The tablet represented] a sinking ship, broken into two pieces [...] low on the left there was a cartouche with the writing: "Salvatore Barbabianca \& Sons for grace received." But it did not tell which grace, even if the whole background of the ex voto was sulfuryellow, so that who wanted could understand. Behind the altar boy there was the municipal band in its entirety, playing [...], still behind Father Imbornone with two more altar boys who embalmed him with incense. [...] After him there was the whole family Barbabianca [...] Then came the servants [...], and after them all the warehousemen of Vigata... ${ }^{61}$

As the hyperbolic devotional acts show, religion is part of the theatrical character Camilleri attributes to the Sicilians: religious rituals are a collective mise-en-scène, a representation scarcely connected to faith, but having a precise social value and often characterized by overacting. Camilleri depicts this dramatic propensity with several episodes of individual or collective fictional performances:

We call "tragediatore" someone who, in every occasion, serious or merry, starts making theater, that is, someone who uses tones and attitudes more or less marked with reference to the level of the fact in which he happens to be a character. His "interpretation" has generally the aim of soliciting not the consent, but rather the promptest and most active participation of those that are present during the scene. If the "tragediatore" is really good (and you need an extremely fine ear to distinguish, for example, a whole merry past of cheating in the desperate cry of a widow apparently close to suicide) then the consent of the bystanders is like a prize, a reward; everyone is ready [...] to act as a stooge, to give the right line at the right time. I know well that elsewhere the "tragediatore" is called more simply a comedian, but the reason why in our land we prefer to evoke tragedy instead of comedy is something so obvious for our character -and explained in hundreds of books of thought and of fiction - that it is not worthy to lose more breath on it. [...] It also happens quite frequently that a whole village, instead of a single person, becomes "tragediatore", for fun or for necessity. Something similar happened during the Middle Ages, for the preparation of a sacred representation, when

61 " [La] funzione si svolse alla Matrice, e fu cosa veramente solenne, che meritò d'essere contata e vista. Alle dieci del mattino, in mezzo a due ali di chierichetti che cantavano e a una folla di magazzinieri, giovani di magazzino, impiegati, tutti con rispettive mogliere, Stefanuzzo Barbabianca si presentò sulla porta della chiesa scalzo e con una candela accesa in mano per sciogliere l'altro voto solenne che aveva fatto. Con la testa calata sul petto, la candela alzata, arrivò fino all'altare maggiore dove sostò in doveroso raccoglimento. Poi [...] si stese a pancia sotto, tirò fuori due palmi di lingua e a strascinuni [...] leccò accuratamente lo sporco del pavimento, percorrendo due volte la chiesa intera [...]. Sciolto il voto, si formò la processione, in testa un chierichetto che su di un cuscino di raso teneva la tavoletta $[\ldots]$. Rappresentava [...] una nave che affondava spaccata a metà [...]; in basso a sinistra c'era un cartiglio che portava la scritta: 'Salvatore Barbabianca \& Figli per grazia ricevuta'. Ma non era detta quale, magari se tutto il fondo dell'ex-voto era di un colore giallo-sùlfaro così chi voleva capire capiva. Dietro al chierichetto c'era la banda municipale al gran completo che suonava [...], dietro ancora Padre Imbornone con altri due chierichetti che l'imbalsamavano d'incenso. [...] Appresso a lui c'era tutta la famiglia Barbabianca [...]. Poi venivano i servi [...]. Appresso a loro tutti i magazzinieri di Vigàta..." Camilleri, Un filo, 93-94. 
the totality of the inhabitants of a village cooperated on the staging, guided by a leader and momentarily leaving all office and role [...] And I heard that, in this second postwar period, a young and blond woman deputy of a left party insisted on holding an assembly in a village firmly ruled by the mafia, and where the elements with the most dangerously advanced ideas were the liberal republicans: it was impossible to find someone of the party of the deputy. The mafia boss was informed of the situation, and he said that they could not be so impolite as to impede to a beautiful lady to hold her assembly. The deputy arrived on the established day, she found that the piazza was a sea of red flags and people were as thick as sardines in their box: she could not end a sentence before the applause burst so thunderous as to make the window-panes tremble. In the end, she was carried shoulder-high. ${ }^{62}$

The theatrical character of the rituals is due to the performance's excessive, melodramatic character; the actors' acute sense of "fiction"; and the purely metaphoric value of the religious or civic action. The Sicilians described by Camilleri are a good example of what Erving Goffman ${ }^{63}$ calls "cynical performers," individuals who do not believe in their own actions and who can take "pleasure in their masquerade," because they can "toy at will" with something their audience is supposed to take seriously.

Another example is provided by I pugnalatori, a short novel in which Sciascia narrates the story of an influential prince who organizes a terrorist attack ante litteram. Obsessed with securing ever more power, the prince hires low-class hitmen to stab innocent people in order to undermine the new and frail national government. In the end, the humble hitmen are executed, while the powerful prince maintains his privileges and his institutional position. Indeed, he takes part in a procession as the king's delegate. The procession's spectators are distracted from the religious or spiritual character of the event and comment with irony and resignation on the striking and scandalous presence of the prince in a procession held in honor of a Madonna that was stabbed exactly as his victims.

\footnotetext{
62 “'Tragediatore' è, dalle parti nostre, quello che, in ogni occasione che gli càpita, seria o allegra che sia, si mette a fare teatro, adopera cioè toni e atteggiamenti più o meno marcati rispetto al livello del fatto in cui si trova ad essere personaggio. La sua 'interpretazione' ha in genere lo scopo di sollecitare non tanto il consenso quanto la partecipazione più pronta e attiva da parte di coloro che alla scena si trovano ad assistere. Se il tragediatore è veramente capace (e ci vuole un orecchio estremamente fino per distinguere, che so, tutto un allegro passato di corna messe a tinchitè nelle urla disperate di una vedova apparentemente prossima al suicidio) allora il consenso degli astanti è come un premio, una gratifica; tutti sono pronti [...] a fare da spalla, a dare la battuta giusta al tempo giusto. So bene che il 'tragediatore' altrove viene più semplicemente chiamato 'commediante', ma perché da noi si preferisca tirare in ballo la tragedia piuttosto che la commedia è cosa così caratterialmente ovvia - e spiegata in centinaia di libri di pensiero e di fantasia - che non è manco il caso di perderci altro fiato sopra [...]. Succede magari con qualche frequenza che a diventare 'tragediatore', per gioco o per necessità, sia tutto un paese anziché una singola persona. Similmente a quanto avveniva nel Medioevo per la preparazione di una sacra rappresentazione, che la totalità degli abitanti di un paese collaborava all'allestimento, rimettendosi nelle mani di un capintesta e abbandonando momentaneamente ogni carica e ruolo [...] E mi è giunta voce che, negli anni di questo secondo dopoguerra, una giovane e bionda deputatessa di un partito di sinistra si era intestata a tenere un comizio in un paese saldamente governato dalla mafia, e dove gli elementi di idee pericolosamente più avanzate erano i liberali repubblicani: del partito al quale apparteneva la deputatessa non se ne trovava uno manco a pagarlo a peso d'oro. Della situazione venne avvisato il capomafia, il quale disse che non si poteva essere così scortesi da impedire il comizio a una bella signora. La deputatessa arrivò nel giorno stabilito, trovò la piazza che era un mare di bandiere rosse e di persone messe una sopra l'altra come le sarde nella scatola: non faceva in tempo a finire una frase che gli applausi scoppiavano così fragorosi da fare tremare i vetri. Alla fine venne portata in trionfo." Andrea Camilleri, $L a$ strage dimenticata (Palermo: Sellerio, 2009 [1984]), 49-50.

${ }^{63}$ Erving Goffman, The Presentation of Self in Everyday Life (New York: Doubleday, 1959), 18.
} 
According to Sciascia, ${ }^{64}$ the Sicilian pantheon is shaped on the model of the traditional feudal society. Sicilian people deem the vice-king to be more powerful than the king himself because of his greater proximity and direct influence on them. In the same way, the saints and the Virgin Mary are viewed as being closer to the earth and consequently more powerful than Christ or God himself. The cult of the saints and related practices - including processions - were established by the lower classes, and were only partly and in second instance controlled by the Catholic Church. Sciascia ${ }^{65}$ presents Sicilian religiosity as materialistic, anti-metaphysical, anti-Catholic, and rather "pagan": a "religion without transcendence." The author draws a distinction between the carefully defined ecclesiastical liturgy and the actual practices that were still alive in the 20thcentury Sicily, such as drowning or throwing the statues of the saints, or throwing food against them.

Furthermore, Sciascia describes the association between the identity of a local community and the cult of a particular saint. Processions and other religious practices assume the value of an affirmation of local identity and can generate tremendous conflict between followers of different saints from different communities. Both micro-historiography and literature bear testimony to this aspect of popular religiosity, which can be compared to contemporary fanaticism for athletic teams. It is a phenomenon that can fruitfully be interpreted in light of game theory, in particular with the category of "agon" (competition) developed by Roger Caillois. ${ }^{66}$ For example, the tale "Guerra di Santi” by Giovanni Verga efficaciously describes a fight among two rival neighborhoods, one devoted to San Rocco and the other to San Pasquale, on the occasion of a procession:

Suddenly, as San Rocco was proceeding calmly on his way beneath his baldacchino surrounded by [...] a huge number of lighted candles, and the band leading the procession, there was a general stampede and massive uproar, and all hell broke loose. There were priests rushing about with their cassocks flying, heads being thumped with clarinets and trumpets, women screaming, blood flowing in rivers, and blows raining down like overripe pears right under the nose of the blessed San Rocco. The chief of police, the mayor, and the carabinieri all rushed to the scene. The injured were carried off to hospital with broken limbs, and the main troublemakers were clapped into jail for the night. The festival had turned into a Punch and Judy show, and the saint returned to the church at more of a gallop than a walking pace. ${ }^{67}$

The ironic effect of this passage is produced by upsetting the coded ritual: the solemnity of the procession turns into comedy, the composure of the priests into an agitated getaway, the musical instruments into weapons, the pious chants into shrieks, and the calm pace into running. In several

\footnotetext{
${ }^{64}$ Leonardo Sciascia, "Feste religiose in Sicilia," Opere 1956-1971 (Milano: Bompiani, 1987 [1970]), vol. 3, 9591222.

${ }^{65}$ Sciascia, "Feste," 1156, 1166.

${ }^{66}$ Roger Caillois, Les jeux et les hommes: Le masque et le vertige (Paris: Gallimard, 1958).

67 "Tutt'a un tratto, mentre San Rocco se ne andava tranquillamente per la sua strada, sotto il baldacchino, con [...] un gran numero di ceri accesi tutt intorno, e la banda, la processione, la calca dei devoti, accadde un parapiglia, un fuggi fuggi, una casa del diavolo: preti che scappavano con le sottane per aria, trombe e clarinetti sulla faccia, donne che strillavano, il sangue a rigagnoli, e le legnate che piovevano come pere fradice fin sotto il naso di San Rocco benedetto. Accorsero il pretore, il sindaco, i carabinieri: le ossa rotte furono portate all'ospedale, i più riottosi andarono a dormire in prigione, il santo tornò in chiesa a corsa piuttosto che a passo di processione, e la festa finì come le commedie di Pulcinella." Giuseppe Verga, "Guerra di Santi," Tutte le novelle (Milano: Mondadori, 1987 [1880]), 211. Transl. "War," 101.
} 
tales by $\mathrm{D}^{\prime}$ Annunzio we can find similar literary representations of fights and rivalries in the region of Abruzzo. For example in "La vergine Anna":

But in Holy Week of the year 1857 a great event happened. Between the Confraternity commanded by Don Fileno d'Amelio and the Abbot Cennamele, who was aided by the parochial satellites, broke out a war; and the cause of it was a dispute about the procession of the dead Jesus. Don Fileno wished this ostentation, furnished by the congregation, to issue from the parochial church. The war attracted and enveloped all of the citizens as well as the militia of the King of Naples, residing in the fortress. Popular tumult arose, the roads were occupied by assemblies of fanatical people, armed platoons went around to suppress disorders, the Archbishop of Chieti was besieged by innumerable messages from both parties; much money for corruption was spent everywhere and a murmur of mysterious plots spread throughout the city. ${ }^{68}$

In the tale "Gli idolatri," D'Annunzio describes the cult of the saints as a form of idolatry. In a situation of tension due to strange luminous phenomena seen in the sky, the inhabitants of the village of Radusa venerate the relic of Saint Pantaleone and anxiously wait for Pallura, the man who must bring the candles for the cult. Pallura returns wounded and robbed, and the people, possessed by a sudden fury, blame the inhabitants of the rival village, Mascàlico. They place the statue of Saint Pantaleone at the head of a war-like and wild procession ("processione di battaglia"69):

And the phalanxes, armed with scythes, with sickles, with hatchets, with hoes and with muskets, reunited on the square before the church. And the idolaters shouted: "Saint Pantaleone!" [...] When the idol, borne upon the shoulder of four Hercules, appeared presently between the pilasters of the vestibule, and shed rays from its aureole, a long, breathless passion passed over the expectant crowd, a noise like a joyous wind beat upon all foreheads. The column moved. And the enormous head of the Saint oscillated on high, gazing before it with two empty eyes. ${ }^{70}$

Once in Mascàlico, the Radusani start slaughtering the population; a furious battle ensues between the men of the two villages that ends only when the "idol" of Saint Pantaleone falls on the ground of the enemy church. The recurring term of "idolatry" suggests the fetishism and the materialism of the cult of the saints, which ends in violence contradicting all Christian values. The phenomena of local identification and competition associated with the cult of the saints and the procession can be catalogued as a basic component of the socio-political dimension of popular religiosity. Sciascia writes:

\footnotetext{
68 "Ma nella Settimana Santa del 1857, sorse un grande avvenimento. Tra la Confraternita capitanata da don Fileno d'Amelio e l'abate Cennamele, coadiuvato dai satelliti parrocchiali, scoppiò la guerra; e ne fu causa un contrasto per la processione di Gesù morto. Don Fileno voleva che la pompa, fornita dai congregati, uscisse dalla chiesa della Confraternita; 1'abate voleva che la pompa uscisse dalla chiesa parrocchiale. La guerra attrasse e avviluppò tutti i cittadini e le milizie del Re di Napoli, residenti nel forte. Nacquero tumulti popolari, le vie furono occupate da gente fanatica, pattuglie armigere andarono in volta per impedire i disordini, il conte Arcivescovo di Chieti fu assediato da innumerevoli messi d'ambo le parti; corse molta pecunia per corruzioni; un mormorìo di congiure misteriose si sparse per la città." Gabriele D'Annunzio, "La vergine Anna," Tutte le novelle (Milano: Mondadori, 1992 [1884]), 153-154. Transl. "The Virgin," 250.

${ }^{69}$ Gabriele D’Annunzio, “Gli idolatri,” Tutte le novelle (Milano: Mondadori, 1992 [1884]), 186.

70 "E la falange, armata di falci, di ronche, di scuri, di zappe, di schioppi, si riunì sulla piazza, dinanzi alla chiesa. E gli idolatri gridavano: San Pantaleone! [...] Quando l'idolo, portato su le spalle da quattro ercoli, si mostrò alfine tra i pilastri del vestibolo, e s'irraggiò alla luce aurorale, un lungo anelito di passione corse il popolo aspettante, un fremito come d'un vento di gioia volò sopra tutte le fronti. E la colonna si mosse. E la testa enorme del Santo oscillava in alto, guardando innanzi a sé dalle sue orbite vuote." D'Annunzio, "Gli idolatri," 185. Transl. "The idolaters," 131.
} 
But a religious feast - what is a religious feast in Sicily? It would be easy to answer that it is everything but a religious feast [...] It is, above all, an existential explosion; the explosion of the collective es, in a land where the collectivity only exists at the es-level. Because it is only during the feast that the Sicilian abandons his condition of lonely man, which is the condition of his vigilant and painful super-ego [...], to find out he is part of a social class, of a city. ${ }^{71}$

\section{From religious procession to revolution}

If, as we have seen, it is difficult to separate religious from civil processions, it is possible instead to draw a distinction between "enthusiastic" "72 and "ordered" processions. We said that thanks to ordered civil-religious processions and uninhibited popular feasts, revolutionary passions are often bridled, controlled, and exorcised with not much more damage to the ruling class than the sacrifice of some barrels of wine. In other cases, nevertheless, the opposite happens: an ordered religious procession can suddenly turn into a violent and revolutionary manifestation. Examples of this are numerous in our corpus.

In La Briganta, a religious procession ends with the popular occupation of communal lands being usurped by the lords and the authorities of the new national government:

That year everything began as usual: it seemed that the feast should triumph, as always, stronger than any war or calamity [...] Precisely in those days the authorities had revoked the sowing right on the communal land [...] So, after all, despite the solemn preparations, there was no time for the feast that year: everything happened the same day when a procession of men started from the sanctuary in the direction of the communal land. They were many, and they held olive branches in their hands, not as a sign of peace but as a reminder of the ancient rights the community boasted on the communal woods [...]. The procession was opened by a hundred women, oblivious of any prudence, with crosses, white flags prepared very secretly and now unfolded to defy the destiny. They sang litanies and at the same time they danced, shouting every now and then, viva Maria, down with Vittorio! The trodden soil lifted a thick dust hiding men and beasts, so thick that at a certain moment you could not see anything other than a big cloud of white dust advancing, whirling, through the land..$^{73}$

\footnotetext{
71 "Ma una festa religiosa - che cosa è una festa religiosa in Sicilia? Sarebbe facile rispondere che è tutto, tranne che una festa religiosa [...]. È, innanzi tutto, una esplosione esistenziale; l'esplosione dell'es collettivo, in un paese dove la collettività esiste soltanto a livello dell'es. Poiché è soltanto nella festa che il siciliano esce dalla sua condizione di uomo solo, che è poi la condizione del suo vigile e doloroso super-io [...] per ritrovarsi parte di un ceto, di una classe, di una città." Sciascia, "Feste," 1162-1163.

${ }^{72}$ We use the term "enthusiasm" without reference to particular theological meanings, but more generally as "a condition of vehement psychical excitement or inordinate exaltation," similar to the state of "intoxication" characterizing the Dionysian rituals (see Ludwig Radermacher, "Enthusiasm," in James Hastings (ed.), The Encyclopedia of Religion and Ethics (Edimburg: T\&T Clark, 1912), 316-317.

73 “Quell'anno tutto cominciò come al solito: sembrava che la festa dovesse trionfare, come sempre, più forte d'ogni guerra e d'ogni calamità [...]. Proprio in quei giorni era stato revocato dalle autorità il diritto di semina [...] sul fondo comunale $[\ldots]$. Così dopotutto, nonostante i preparativi solenni, non ci fu tempo per la festa, quell'anno: tutto accadde il giorno stesso in cui una processione di uomini si partì proprio dal santuario in direzione del fondo. Erano in tanti e tutti avevano in mano rami d'ulivo, non in segno di pace ma per ricordare gli antichi diritti che la comunità vantava sui boschi comunali [...]. La processione era aperta da un centinaio di donne, dimentiche di ogni prudenza, con croci e bandiere bianche preparate in gran segreto e adesso spiegate a sfidare il destino. Cantavano litanie e allo stesso tempo ballavano, gridando di tanto in tanto, viva Maria, abbasso Vittorio! La terra calpestata si sollevava fitta nascondendo uomini e bestie, tanto fitta che a un certo punto non si vide altro che una gran nuvola di polvere bianca che avanzava turbinosa attraverso la campagna." Maria Rosa Cutrufelli, La briganta (Milano: Frassinelli, 2005 [1990]), 53-55.
} 
In this enthusiastic procession, religious symbols intermingle with civil motifs: the olive branches are a symbol of ancient rights, the white flags symbols of the old Bourbons' monarchy, the contrasting invocations to Mary and to the new king Vittorio symbols of a mentality in which the struggle for the civil freedom cannot be disjoined from the religious "ground bass." In the end, the soldiers of king Vittorio arrive and massacre the people on the communal land. The initiative of the oppressed peasants, who had become aware of their state and were trying to regain their subjectivity and freedom, is suffocated by the army in the worst negation of subjectivity. The peasants are undressed, executed and left on the square of a village which is not their own. Many of them remain bodies without a name, the only thing they had owned in life. ${ }^{74}$

In Le armi l'amore, a mass of peasants participating in a religious procession attacks the foreign revolutionaries exterminating them:

“... and then the bells will sound faster and the procession will appear from behind the walls of the houses, down there: the noise of the bells will cover the voices, but they will be able to see the mouths even open and close, as if they were singing, and they will see the standards, the ferocious color of the purple and white and gold of the frenzied images deformed in the motionless air by the impetus of running and then the oscillating canopy and the golden sun of the monstrance lifted up and then the man with the huge cross [...] the procession will suddenly break up in a swarm of men and women and kids who will run up on the street and on all the slope [...]: and now, in the middle of the limpid and furious sound of the bells, he will hear the blended shouts and he will see them coming up very close dealing against him the points of their pitchforks [...] and he will see the faces multiplying and the billhooks' blades and the sticks... ${ }^{75}$

Here again, Catholic symbols are connected, on the one hand, to a frenetic, furious, and irrational passion culminating in murder and, on the other hand, to an action which is not religious, but rather socio-political (the refusal of the revolutionary foreigners who want to change a millennial, atavist system). A very similar description can be found in Alianello, where a wild crowd, singing church songs and bearing religious symbols, furiously attacks and exterminates a group of soldiers of Garibaldi's army (similarities in italics):

Then the bell started ringing again. A violent, almost furious beat [...]. And in the square, a crowd, strange to see for its different colors, impetuously flowed out of the church [...] 'A procession' said the chief of the platoon. Indeed, they were singing, acute voices, deep voices, heavy voices. [...] The crowd gathered together, put itself in order and advanced. [...] Men armed with all sorts of weapon came down the paths [...] Confraternities with their cowls and habits, their banners, the statues of the saints, the stick-cross ahead everyone, as the breaking of a mountain dyke, always singing not war songs, but the mild litanies of the saints, while women, the beautiful women of the Sannio [...] made the choir with fierce pride: "Ora pro

\footnotetext{
${ }^{74}$ Cutrufelli, La briganta, 64-65.

75 “... e poi le campane suoneranno più in fretta e da dietro i muri delle case, giù in basso, apparirà la processione: il rumore delle campane coprirà le voci, ma potranno vedere persino le bocche aperte e chiuse, come se cantassero, e vedranno gli stendardi, il colore feroce della porpora e il bianco e l'oro delle frenetiche immagini deformate nell'aria immobile dall'impeto della corsa e poi il baldacchino dondolante e il sole d'oro dell'ostensorio levato in alto e poi l'uomo con la croce enorme che gli uscirà dritta dal ventre cadrà in ginocchio sotto il peso sulla strada in salita e poi si rialzerà mentre la processione si disfarà di colpo in un brulicare di uomini e di donne e di ragazzi che correranno sù per la strada e su tutto il pendio [...]: e ora, in mezzo al suono limpido e furioso delle campane, sentirà le voci le urla mescolate e li vedrà salire vicinissimi vibrando contro di lui le punte dei forconi e [...] vedrà le facce moltiplicarsi e le lame delle roncole e i bastoni..." Tadini, Le armi, 481-482.
} 
nobis!" [...] They were almost dancing, accompanying themselves with their acute voices, while they dealt hatchets or delivered long knives... 76

In Alianello we once more find the intermingling of unbridled, furious passion with religious symbols and political action. Here again the starting point of the degenerated procession is the church. Just like in Maria Rosa Cutrufelli's novel, the role of the fierce and disinhibited women is underlined: it is a significant component of the reversed dimension of the enthusiastic moment that follows the ordered beginning of the procession.

According to Marin, the passage from order to disorder is more likely to take place at the beginning or at the end of the procession, because the moments when the parading mass gathers together or disbands "represent borders between the law of 'normal' everyday spaces and places and the law of the parade." ${ }^{77}$ In our literary texts, disorder and enthusiasm do not belong to the liminal moments of the beginning and end, but stem instead from the very heart of the space and time of the procession. It is not an interruption, but a metamorphosis in the character of the procession itself. This singular phenomenon can be interpreted in light of the theory developed by Kathleen Ashley and Pamela Sheingorn, ${ }^{78}$ and by Leone:

Whereas inside the place of worship, liturgy scrupulously regulates the relation between transcendence and immanence, as soon as the simulacrum of the sacred leaves its environment of belonging and undertakes its processional journey through the profane world, it exposes itself to all the risks of unpredictable contamination entailed by the dramatic multiplication of agencies involved in the ritual. ${ }^{79}$

Due to their collective character, processions "escape rigid control," despite the efforts of the Catholic church to codify their liturgy. Outside the sacred space of the church, there is room for unpredictable reversals of the ritual, and this explains the melting of sacred chants and bestial violence, of symbols of salvation (the cross) and of death (rough peasant weapons), and the prevailing of enthusiasm over order.

Along with the powerful aesthetic effect of recurring elements such as the irrational and enthusiastic movement of the mass, the noise (shouts, shoots, firecrackers, etc.) covering the words, the prolonged sound of the bells, the precious or spectacular liturgical objects, the colors of the clothes of different categories of people melted in the crowd, and the clouds of dust raised by their frenetic steps, we can cite two frequent aesthetic features in the representation of the

\footnotetext{
76 “Allora la campana riprese a suonare. Un batter violento, furibondo quasi [...]. E sul piazzale sgorgò d'impeto dalla chiesa una folla strana a vedersi nei suoi diversi colori. [...] 'Una processione', disse chi stava a capo del plotone. Infatti cantavano, voci acute, voci gravi, voci pesanti. [...] La folla si raccolse, s'ordinò, venne avanti. [... Scendevano] lungo i sentieri [...] uomini armati d'ogni sorta d'arme [...]. Fraterie e confraternite, coi loro cappucci, i sai, i loro labari, le statue dei santi, la croce astata innanzi a tutti, come rotta d'una diga montana, sempre cantando non canzoni di guerra ma le miti litanie dei santi, mentre le donne, le belle e solide donne del Sannio [...] facevan coro con rapinosa fierezza: 'Ora pro nobis!' [...]. Quasi danzavan le donne, accompagnandosi con le loro voci acute, mentre vibravano accette o calavano i lunghi coltelli...” Carlo Alianello, La conquista del Sud (Milano: Rusconi, 1972), 186-191.

${ }^{77}$ Marin, "Notes," 224.

${ }^{78}$ Kathleen Ashley \& Pamela Sheingorn, "Sainte Foy on the Loose, Or, The Possibilities of Procession," in Kathleen Ashley \& Wim Hüsken (eds.), Moving Subjects. Processional Performance in the Middle Ages and the Renaissance (Amsterdam \& Atlanta, Rodopi, 2001), 53-67.

${ }^{79}$ Massimo Leone, "Transcendence and Transgression in Religious Processions," Signs and Society 2/2 (2014), 321.
} 
religious processions. The first is the ekphrasis, the description of works of art. In our case, the artworks are mostly rough and primitive statues of the Virgin, evoking the primeval goddess mentioned by Bellah, ${ }^{80}$ and statues of the saints. The second aesthetic feature is the naïve spectacular tricks carried out during the processions.

For example, in I sentieri del cielo the statue of the Virgin is "barely more than a rough silhouette of painted wood, with a dark cape on her shoulders; her eyes were turned up to the sky and her hands joined." ${ }^{11}$ At the end of the procession, the priest pulls a string, the cape of the statue falls, and two doves fly off; the women burst into tears and the men applaud. Similarly, in L'alfiere the small statue of the Virgin, “... covered and enveloped by too much silk and too much gold," 82 is accompanied by the statues of the most venerated Saints and martyrs, "hard, rigid, roughly sketched out of a rough stump" $" 83$ :

The priests chanted psalms and the crowd sang the lauds of the Virgin, with some shouts [...] only overwhelmed by [...] the firecrackers exploding in the middle of the street. [...] And everything rose up in big, fat dust, smelling of gunpowder, golden of sun, white of smoke, a blanket covering everything like a thick padding. The only things bursting out of it were the vivid points, the dazzling sparkles of the gold and the sour acuity of the chants and of the shouts. In the square, everything was ready for the arrival of the Virgin, $[\ldots]$ some little girls with white dresses were singing a hymn or something that the band erased with its big brass instruments and the resounding of the bass drum... ${ }^{84}$

After the speech of the civil authority, filled with patriotic rhetoric, a child dressed like an angel appears from above as a deus ex machina and is lowered with ropes and a pulley down to the statue of the Virgin, to whom he offers a bunch of flowers shouting "Viva Maria":

And the people repeated that shout, their real shout, the one that never changes for kings or republics, and they cast it up to the sky, until it vanished with the sky itself: "Viva Maria!"85

\section{Conclusions}

We have closely analyzed some of the numerous representations of processions in contemporary Italian literature. While it is hard to define an Italian civil religion based on Bellah's model of an American one, it is certainly possible to identify a popular religion with a political-civic

\footnotetext{
${ }^{80}$ Bellah, "The Five."

81 “... poco piú di una grezza silouette di legno dipinto, con un mantello scuro sulle spalle, gli occhi rivolti al cielo e le mani giunte.” Luigi Guarnieri, I sentieri del Cielo (Milano: Rizzoli, 2008), 111.

82 “... rivestita e avvolta da troppe sete e troppi ori.” Alianello, L'alfiere, 226.

83 “.... duri, rigidi, grossolanamente sbozzati fuor da un ceppo grossolano.” Alianello, L'alfiere, 226.

84 "I preti salmodiavano e la folla cantava le laudi della Vergine, con certi urli tutti gola e testa [...] solo sopraffatti [...dai] mortaletti che scoppiavano lì in mezzo alla strada [...] E tutto levava su un polverone grasso, fetente di odor di sparo, dorato di sole, bianco di fumo, un coltrone che ricopriva ogni cosa come una ovatta spessa. Solo ne sprizzavano fuori, vividi punti, i luccichii abbaglianti degli ori e l'acutezza agra dei canti e degli strilli. In piazza tutto era pronto per l'arrivo della Madonna. [...] delle bimbe vestite di bianco cantavano un inno o qualcosa che la banda coi suoi grossi ottoni e col rintronar della grancassa scancellava via...” Alianello, L'alfiere, 226-227.

85 "E il popolo riprese quel grido, il suo vero grido, che non muta per re o per repubbliche, e lo scagliò su al cielo, sino a che svanisse col cielo: 'Viva Maria!"” Alianello, L'alfiere, 233.
} 
character, composed of a Catholicism in which the sub-Christian 'ground bass' religion is still alive. In literature, this Catholic / ground bass civil religion is often represented through the motif of the procession, in which sub-Christian, Catholic, and civil symbols are deeply interconnected.

In the works we examined, it was not possible to develop a typology of procession as a literary topos based on a clear distinction between civic and religious cortèges. More productive was the distinction between ordered and disordered, or enthusiastic, processions. In both cases, the persons involved in the processions, mainly poor peasants, act mostly as non-subjects, as a mass deprived of a deep self-consciousness and self-determination, dominated by strong collective passions. These passions sometimes flow spontaneously and sometimes are manipulated by the ruling class through an elementary and powerful sacral symbolical apparatus. We can define the difference between ordered and enthusiastic procession by adopting Victor Turner's distinction between structure and communitas. "Structure" refers to "hierarchical arrangement of roles and statuses within a social group," 86 while communitas "breaks in through the interstices of structure, in liminality, $" 87$ and is connected to a feeling of marginality and inferiority:

\footnotetext{
It is almost everywhere held to be sacred or "holy", possibly because it transgresses or dissolves the norms that govern structured and institutionalized relationships and is accompanied by experiences of unprecedented potency. [...] Instinctual energies are surely liberated by these processes, but [...] communitas is not solely the product of biologically inherited drives released from cultural constraints. Rather it is the product of peculiarly human faculties, which include rationality, volition, and memory, and which develop with experience of life in society...88
}

In our corpus, enthusiastic processions - despite their unbridled character - often build communitas only in opposition to an enemy, a potentially menacing external element that becomes the object of a furious hatred. As a consequence, while ordered processions are a representation and an affirmation of social structure, enthusiastic processions enact communitas. Enthusiasm, however, implies not only instinct, but also the volition and memory that allow the group to identify itself in contrast to an enemy that assumes a function analogous to that of the "bouc emissaire." 89

It is possible to think the enthusiastic procession and the "theatrical" procession as the two poles of a continuum. As we have seen, the theatrical collective performances described by Camilleri and Sciascia imply a strong sense of structure. Each actor is conscious of his role and plays it scrupulously, according to his social position. Nevertheless, the fictional character of these events is often underlined, thus showing a lack of sincere adhesion of the actors (the "cynical performers"). Therefore, in this case the actors involved in the procession likewise fail to act as subjects, i.e. as persons adopting a certain set of values and willingly and coherently acting according to them..$^{90}$ As a consequence, despite their differences, both kinds of processions are

\footnotetext{
${ }^{86}$ Merlino, "Sicilian," 123.

${ }^{87}$ Victor Turner, The Ritual Process: Structure and Anti-Structure (London: Routledge, 1969), 128.

${ }^{88}$ Turner, The Ritual, 128.

${ }^{89}$ René Girard, Le bouc émissaire (Paris: Grasset, 1982).

${ }^{90}$ See Greimas and Courtès, Sémiotique, 179-180.
} 
"a group activity that minimizes individuality" 91 and both entail a sentiment of "effervescence,"92 despite the differences in quality between them: irrational enthusiasm in the one case, intellectual amusement for the sake of fictional-theatrical representation in the other.

An elementary religiosity, a collective and anonymous strength, the identification of the collectivity with the material icon of the deity (e.g. the statue of Saint Pantaleone for D'Annunzio's "idolaters," the cross in Tadini and Alianello), to which we can add the act of following a religious symbol and a powerful emotive impact: all of these are elements which the writers have identified in Italian culture and represented in their texts. The act of following can be interpreted as a metaphorical enacting of Jesus's invitation to his disciples ("Whoever wants to be my disciple must deny themselves and take up their cross and follow me," Matthew 16: 24). The act of following represented in our corpus, however, fetishizes the materiality of the symbol and entails a physical, more than spiritual, sense of abandonment: not the ascetic renunciation to earthly goods, but the sensual experience of release through an excess of sensual stimuli. Indeed, in the passages we analyzed, the descriptions abound with of almost unbearable sounds, violent colors, and other extraordinary visual elements (e.g. clothes, ornaments, etc.), which contribute to what we called the enthusiastic state of the processions' actors.

This trait is closely bound to the recurring aesthetic features of procession as a literary motif: colors, movements, sounds, smells, statues, and other symbols, all expressing the peculiar semiotic style of the picturesque religion characterizing in particular Southern Italy. Such a religion can have complex manifestations, ranging from order to disorder, from fervent enthusiasm to cynical theatrical fiction, from apathetic following to furious murder, from hyperbolic manifestations of pious love to wild hatred. This religious substratum is so powerful that the national symbolical apparatus relies on its rituals and symbols in order to dissolve revolutionary tensions and to foster people's identification with established institutions. In literary representations, elementary, rough religious symbols and rituals evoke the strongest emotional response. As a result, the political discourse has to reproduce or integrate this religious element in order to be efficacious.

Moreover, paradoxically, the civil-national discourse has to integrate these religious motifs even when its political ideology contrasts with Catholicism and with the ground bass on which this religious semiotic style is based. This paradox characterizes the whole history of Italy as a nation. As Sciascia points out, for example, the cortèges of the Fasci Siciliani were opened both by the International's flags and by the images of the patron saints, and the communists have been among the most eager supporters and organizers of the religious feasts, especially in the villages. ${ }^{93}$ The same is true for liberals, fascists, radicals, masons, socialists and all the political actors in Sicily

\footnotetext{
${ }^{91}$ Flanigan, "The moving," 39.

${ }^{92}$ Emile Durkheim, Les formes élémentaires de la vie religieuse: le système totémique en Australie (Paris: PUF, 1968 [1912]).

93 "I cortei dei Fasci Siciliani si aprivano con le bandiere dell'Internazionale e le immagini dei santi patroni; e i comunisti sono sempre stati, nei paesi, tra i primi e più zelanti sostenitori delle feste religiose." Sciascia, "Le feste," 1148 .
} 
and in Southern Italy: none of them have been able to ignore the symbolical apparatus of this heterogeneous but deeply rooted religiosity.

\section{REFERENCES}

Alianello Carlo (1972), La conquista del Sud, Milano, Rusconi.

- (2011a), L'alfiere, Milano, Rizzoli ( $1^{\text {st }}$ ed. 1942, Torino, Einaudi).

- (2011b), L'eredità della priora, Venosa, Osanna ( $1^{\text {st }}$ ed. 1963, Milano, Feltrinelli).

Anderson Benedict (1983), Imagined Communities, London - New York, Verso.

Ashley Kathleen and Sheingorn Pamela (2001), "Sainte Foy on the Loose, Or, The Possibilites of Procession" in Kathleen Ashley and Wim Hüsken (eds.), Moving Subjects. Processional Performance in the Middle Ages and the Renaissance, Amsterdam-Atlanta, Rodopi, 5367.

Banti Anna (1967), Noi credevamo, Milano, Mondadori.

Bianciardi Luciano (2008), Le cinque giornate. Bisognerebbe anche occupare le banche, Viterbo, Stampa alternativa ( $1^{\text {st }}$ ed. 1969, Aprire il fuoco, Milano, Rizzoli).

Bellah Robert. N. (1967) "Civil Religion in America" in Daedalus, 1, 1-21, http://www.robertbellah.com/articles 5.htm (accessed on 1 December 2015).

- (1974), "Le cinque religioni dell'Italia moderna" in Fabio L. Cavazza e Stephen R. Graubard (eds.), Il caso italiano, Milano, Garzanti; transl. "The Five Religions of Modern Italy" in Robert N. Bellah and Steven M. Typton (2006), The Robert Bellah Reader, DurhamLondon, Duke University Press.

Bloch Marc (1993), Apologie pour l'histoire ou métier d'historien, Paris, Armand Colin (1 ${ }^{\text {st }}$ ed. 1949, Paris, Armand Collin).

Caillois Roger (1958), Les jeux et les hommes: Le masque et le vertige, Paris, Gallimard.

Camilleri Andrea (1993), La bolla di componenda, Palermo, Sellerio.

- (2004), Un filo di fumo in Romanzi storici e civili, Milano, Mondadori, 4-107 (1 ${ }^{\text {st }}$ ed. 1980, Milano, Garzanti).

- (2009), La strage dimenticata, Palermo, Sellerio ( $1^{\text {st }}$ ed. 1984, Palermo, Sellerio).

- (2010), Lo stivale di Garibaldi, Catania, Stilos.

Croce Benedetto (1932), Storia d'Europa nel secolo decimonono, Bari, Laterza.

Cutrufelli Maria Rosa (2005), La briganta, Milano, Frassinelli ( $1^{\text {st }}$ ed. 1990, Palermo, La luna).

Dal Lago Alessandro (ed.) (1999), Identità nazionale e religione civile in Italia, Rassegna italiana di sociologia, 2.

D’Annunzio Gabriele (1992), "La vergine Anna" in Tutte le novelle, Milano, Mondadori, 131177; transl. Raphael Mantellini (1920), "The Virgin Anna” in Tales of my Native Town, New York-London, Doubleday, Page \& Co, 215-287 (1 ${ }^{\text {st }}$ ed. 1884, “Annali d'Anna” in "Fanfulla della domenica").

- (1992), "Gli idolatri” in Tutte le novelle, Milano, Mondadori, 178-190; transl. Raphael Mantellini (1920), "The idolaters" in Tales of my Native Town, New York-London, Doubleday, Page \& Co, 119-139 (1 $1^{\text {st }}$ ed. 1884, "Il fatto di Mascàlico" in "Fanfulla della domenica").

De Certeau Michel (1983), "L'histoire, science et fiction” in Le genre humain, 7/8, 151-152.

Di Nola Alfonso M. (2001), Gli aspetti magico-religiosi di una cultura subalterna italiana, Torino, Bollati Boringhieri ( $1^{\text {st }}$ ed. 1976). 
Dumezil Georges (1966), La religion romaine archaïque, avec une appendice sur la religion des Etrusques, Paris, Payot.

Durkheim Emile (1968), Les formes élémentaires de la vie religieuse: le système totémique en Australie, Paris, PUF ( $1^{\text {st }}$ ed. 1912, Paris, F. Alcan $)$.

Eisler Riane (1987), The Chalice and The Blade: Our History, Our Future, San Francisco, Harper Collins.

Flanigan Clifford C. (2001), “The Moving Subject: Medieval Liturgical Processions in Semiotic and Cultural Perspective" in Kathleen Ashley and Wim Hüsken (eds.), Moving Subjects. Processional Performance in the Middle Ages and the Renaissance, Amsterdam-Atlanta, Rodopi, 35-51.

Girard René (1982), Le bouc émissaire, Paris, Grasset.

Goffman Erving (1959), The Presentation of Self in Everyday Life, New York, Doubleday.

Gramsci Antonio (1971), Il materialismo storico e Benedetto Croce, Roma, Editori Riuniti (1 ${ }^{\text {st }}$ ed. 1948, Torino, Einaudi).

Greimas Algirdas J. and Courtès Joseph (1979), Sémiotique: dictionnaire raisonné de la théorie du langage, Paris, Hachette.

Guarnieri Luigi (2008), I sentieri del Cielo, Milano, Rizzoli.

Koff Sondra Z. and Koff Stephen P. Koff (2000), Italy: from the First to the Second Republic, London: Routledge.

Leone Massimo (2002), "Processioni - Il percorso circolare che trasforma" in Golem Indispensabile, http://www.golemindispensabile.it

- (2014), "Transcendence and Transgression in Religious Processions" in Signs and Society, 2/2, 314-349.

Levi Carlo (1954), Cristo si è fermato a Eboli, Torino, Einaudi (1st ed. 1945, Roma, Einaudi).

Machiavelli Niccolò (2000), Discorsi sopra la prima deca di Tito Livio, Torino, Einaudi; transl. (1674), Discourses upon the First Decade of T. Livius, London, Charles Harper $\left(1^{\text {st }}\right.$ ed. 1531, Roma, Antonio Blado).

Marin Louis (1987), "Notes on a Semiotic Approach to Parade, Cortege, and Procession" in Alessandro Falassi (ed.), Time out of time. Essays on the festival, Albuquerque, University of New Mexico Press, 220-230.

Marx Karl and Engels Friedrich (1932), Die deutsche Ideologie: Kritik der neuesten deutschen Philosophie in ihren repräsentanten, Feuerbach, B. Bauer und Stirner, und des deutschen Sozialismus in seinen verschiedenen Propheten 1845 - 1846, Wien, Verlag für Literatur und Politik.

Merlino Rossella (2014), "Sicilian Mafia, Patron Saints, and Religious Processions: The Consistent Face of an Ever-Changing Criminal Organization" in Californian Italian Studies, 5/1, 109-129.

Perrot Marie-Dominique, Rist Gilbert and Sabelli Fabrizio (1992), La mythologie programmée: l'économie des croyances dans la société moderne, Paris, Presses Universitaires de France.

Ponzo Jenny (2012), "I discorsi del Presidente Napolitano sull'unità nazionale come professione di fede: per uno studio semiotico della religione civile" in Lexia, rivista di semiotica, 11/12, 377-394.

- (2013a), “Genius loci et identité nationale: représentations de l'espace dans la narrative italienne sur le Risorgimento" in Paola Polito e Alberto Roncaccia (eds), Entre espace et paysage. Pour une approche interdisciplinaire, Lausanne, Etudes de Lettres, 167-182. 
- (2013b), "Le opere d'arte come simboli politici nella narrativa sul Risorgimento (XX secolo)" in Elena Pirvu (ed.), L'italiano nel mondo, a 150 anni dall'Unità d'Italia. Atti del convegno internazionale di studi di Craiova, 16-17 settembre 2011, Craiova, Universitaria, 370-378.

- (2015), La narrativa di argomento risorgimentale (1948-2011), Roma, Aracne, tomes 1-2.

Radermacher Ludwig (1912), "Enthusiasm" in James Hastings (ed.), The Encyclopedia of Religion and Ethics, Edinburgh: T\&T Clark, 316-317.

Renan Ernest (1991), Qu'est-ce qu'une nation?: Texte intégral, Paris, P. Bordas et fils (1 ${ }^{\text {st }}$ ed. 1882, Paris, C. Lévy).

Rousseau Jean-Jacques (1985), Du contrat social, ou Principes du droit politique, Paris, Bordas ( $1^{\text {st }}$ ed. 1762, Amsterdam, M. M. Rey).

Rusconi Gian Enrico (1997), Patria e Repubblica, Bologna, Il Mulino.

Sciascia Leonardo (1978), "Il Quarantotto" in Gli zii di Sicilia, Torino, Einaudi; transl. N.S. Thompson (2013), "Forty-Eight" in Sicilian Uncles, London, Granta, 85-146 (1 $1^{\text {st }}$ ed. 1958, Torino, Einaudi).

— (1987), "Feste religiose in Sicilia" in La corda pazza: scrittori e cose della Sicilia, in Opere 1956-1971, Milano, Bompiani, vol. 3, 959-1222 ( $1^{\text {st }}$ ed. 1970, Torino, Einaudi).

- (2007), I pugnalatori, Milano, Adelphi ( $1^{\text {st }}$ ed. 1976, Torino, Einaudi).

Sironneau Jean-Pierre (2000), Métamorphoses du mythe et de la croyance, Paris, L'Harmattan.

Traniello Francesco (1999), "A proposito di nazione, democrazia e religione civile" in Alessandro Dal Lago (ed.), Identità nazionale e religione civile in Italia, Rassegna italiana di sociologia, 2, 255-268.

Tadini Emilio (1989), Le armi l'amore, Milano, Rizzoli ( $1^{\text {st }}$ ed. 1963, Milano, Rizzoli).

Tomasi di Lampedusa Giuseppe (1958), Il Gattopardo, Milano, Feltrinelli.

Turner Victor (1969), The Ritual Process: Structure and Anti-Structure, London, Routledge.

Verga Giovanni (1987), “Guerra di Santi” in Tutte le novelle, Milano, Mondadori, 211-220; transl. G.H. McWilliam (1999), "War of the Saints" in Cavalleria rusticana and Other Stories, London, Penguin, 101-109 (1 ${ }^{\text {st }}$ ed. 1880 in "Fanfulla della domenica"). 